\title{
Teacher Education for the Twenty-First Century (and a post-pandemic world)
}

Formação de professores para o século XXI (e para um mundo pós pandêmico)

Miriam Jorge*

*Universidade Federal de Minas Gerais, Belo Horizonte, Minas Gerais / Brasil mlsj54@hotmail.com

http:// orcid.org/0000-0001-8397-4916

The Revista Brasileira de Linguistica Aplicada (RBLA - The Brazilian Journal of Applied Linguistics) publishes its special issue on Teacher Education for the twenty-first century within the context of the COVID-19 pandemics. In April 2020, the world is grieving the loss of normalcy, the vulnerability of life, and the fear of economic decline.

Amidst a global crisis and closed schools and campuses, the world is facing the challenge of providing remote education for children, teenagers, and adults. 2020 is a time that leads teacher educators to, once more, rethink the roles of teachers and teacher education for the twenty-first century. The wounds of humanity have been opened by the spread of a virus, exposing persistent inequalities based on race, gender, and social class. It is time to bolster our demands for social justice education, technology equity, and our commitment to human rights.

Global populations are facing fear, anxiety, and grief. Uncertainties coexist with reflections upon meanings of a worldwide calamity. Ideological and political representations are tacit to conversations about capitalism, globalization, and even some xenophobic conspiracy theories. As a witness of this unfortunate historical moment, we are compelled to create meanings within the fields of applied linguistics and educational research. What lessons are there for us to learn? What challenges do teachers, learners, families, and communities are facing that research can help to overcome?

This issue of RBLA is not about the pandemic or the horror it causes. It is about the future, as much as it is about the present. The joy and hope that Paulo Freire sees as a requirement for teaching is the primary 
inspiration for the publication of this issue. In the struggle for the soul of teacher education (ZEICHNER, 2014), I believe it is necessary to discuss versions of post-pandemic education. Applied linguists, especially language educators, continue to be vital forces in the reconstructions and transformations that the future requires.

Education is one of the pillars of profound global transformations. Educators, frequently guided by optimism, explore opportunities that every teacher should seize or create. Cynical views of the future include nature degradation, aggravated climate changes, chronic social inequalities, or consumerism that defies natural limits. However, as educators, our collective aim is a twenty-first century that resembles the hopes (in a Freirean meaning) of fewer inequalities and more sustainability.

Optimistic educators are not alone. The Goals for Sustainable Development defined in the United Nations in the 2030 Agenda (UNESCO, 2017) are examples of a global commitment to a better future. The United Nations' 193 member states and the global civil society (social movements, students, religious leaders, among others) defined the 17 Social Development Goals (SDG), for both developed and developing countries. Defined as the blueprint to achieving a better and more sustainable future for all, the SDGs are (UNESCO, 2017):

1. No Poverty - End poverty in all its forms everywhere

2. Zero Hunger - End hunger, achieve food security and improved nutrition and promote sustainable agriculture

3. Good Health and Well-Being-Ensure healthy lives and promote well-being for all at all ages

4. Quality Education - Ensure inclusive and equitable quality education and promote lifelong learning opportunities for all

5. Gender Equality - Achieve gender equality and empower all women and girls

6. Clean Water and Sanitation - Ensure availability and sustainable management of water and sanitation for all

7. Affordable and Clean Energy - Ensure access to affordable, reliable, sustainable and clean energy for all

8. Decent Work and Economic Growth - Promote sustained, inclusive and sustainable economic growth, full and productive employment and decent work for all 
9. Industry, Innovation and Infrastructure - Build resilient infrastructure, promote inclusive and sustainable industrialization and foster innovation

10. Reduced Inequalities - Reduce inequality within and among countries

11. Sustainable Cities and Communities - Make cities and human settlements inclusive, safe, resilient and sustainable

12. Responsible Consumption and Production - Ensure sustainable consumption and production patterns

13. Climate Action - Take urgent action to combat climate change and its impacts

14. Life below Water-Conserve and sustainably use the oceans, seas and marine resources for sustainable development

15. Life on Land-Protect, restore and promote sustainable use of terrestrial ecosystems, sustainably manage forests, combat desertification, and halt and reverse land degradation and halt biodiversity loss

16. Peace, Justice and Strong Institutions - Promote peaceful and inclusive societies for sustainable development, provide access to justice for all and build effective, accountable and inclusive institutions at all levels

17. Partnerships for the Goals - Strengthen the means of implementation and revitalize the global partnership for sustainable development

Despite the goals mentioned before, being globally oriented, each country needs to consider the local specifics that affect their achievement. Crucial to achieving quality education is the training of teachers that can facilitate learning about, through, and for (HOFFMANN; GORANA, 2016) the successful implementation of the SDGs (UNESCO, 2017). Teachers are not solely responsible for such endeavors. However, they play vital roles in any educational project. In the twenty-first century, teacher education needs to reflect the SDGs.

Twenty-first-century teachers have the privilege of experiencing classrooms that were not imagined by previous generations. Classrooms reflect geographical mobility, inclusive pedagogies, and widening participation policies. Learners' identities reveal different languages, nationalities, ethnicities, and social groups. Racially, linguistically, and culturally diverse learners (RLCD) require new ways of learning and teaching. Changes in the makeup of contemporary classrooms may be a fertile field for creating exciting new visions of teacher education engaged 
with achieving the 17 SDGs. This Century should be about education for sustainability and responsible citizenship.

The Brazilian Journal of Applied Linguistics plays the essential role in valuing teacher education as a concern in the field. General linguistic knowledge and applied linguistics knowledge should be part of every teacher's knowledge base and conceptual framework (REAGAN, 1997). The twenty-first-century claims for profound changes in how humanity forges its path. Languages, communication, and discourses that shape and are shaped by human interactions deserve a leading role in education. The leadership of teachers is a fundamental asset to quality education. The transdisciplinary praxis of Applied Linguistics is a desired asset in the twenty-first-century scholarship.

This issue of RBLA celebrates and informs applied linguists, language teachers, educators, and educational researchers through the contributions of scholars committed to teacher education. The authors in this issue have not planned for their papers related to a global crisis. Nonetheless, they are helping us to envision what teacher education means for the twenty-first century. Their contributions to this volume have become part of a historical moment. The moment we all look backward and forward, to make decisions that will permanently affect the future of many. I hope our readers feel inspired by each of the articles in this journal. Long live the teacher! Long live the teacher educator!

\section{References}

HOFFMAN, T.; GORANA, R. (org.). Teaching the Sustainable Development Goals. Bonn: Engagement Global. 2016.

REAGAN, T. The Case for Applied Linguistics in Teacher Education. Journal of Teacher Education, [S.l.], v. 48, n. 3, p. 185-196, 1997.

UNESCO. Education for Sustainable Development Goals. The Global Education 2030 Agenda; UNESCO: Paris, França, 2017.

ZEICHNER, K. The Struggle for the Soul of Teaching and Teacher Education in the USA. Journal of Education for Teaching: International Research and Pedagogy, [S.l.], v. 40, n. 5, p. 551-568, Oct. 2014. 